\title{
Anti-inflammatory and antinociceptive features of Bryonia alba L.: As a possible alternative in treating rheumatism
}

https://doi.org/10.1515/chem-2019-0003

received June 19, 2018; accepted September 24, 2018.

\begin{abstract}
Bryonia species have traditionally been used as a diuretic and laxative, to reduce edema and relieve joint pain. B. alba roots are used especially to treat rheumatic pain and applied to painful joints in Turkish folk medicine. $B$. alba roots were extracted with $n$-hexane, ethyl acetate (EtOAc), and methanol, successively. The carrageenaninduced hind paw edema model and the Whittle method were used to evaluate the anti-inflammatory activity of the extracts in mice. The $p$-benzoquinone-induced abdominal constriction test and tail flick test were used to evaluate the antinociceptive activity of the extracts in mice. DPPHradical-scavenging activity, ABTS radical-scavenging activity, total antioxidant activity, and hydroxyl radicalscavenging activity were assessed. Furthermore, the total phenolic and total flavonoid contents were calculated for all the extracts. The EtOAc extract prepared from $B$. alba roots had the most promising anti-inflammatory, antinociceptive, and antioxidant activities. Moreover, it had high phenolic and flavonoid contents. Therefore, B. alba roots could be alternative treatment method for rheumatic disorders.
\end{abstract}

Keywords: Anti-inflammatory; antinociceptive; Bryonia alba; Cucurbitaceae.

\footnotetext{
*Corresponding author: Esra Küpeli Akkol, Department of Pharmacognosy, Faculty of Pharmacy, Gazi University, Etiler 06330, Ankara, Turkey, E-mail: esrak@gazi.edu.tr

Mert Ilhan, Fatma Tuğçe Gürağaç Dereli: Department of Pharmacognosy, Faculty of Pharmacy, Gazi University, Etiler 06330, Ankara, Turkey

Mert Ilhan: Department of Pharmacognosy, Faculty of Pharmacy, Yüzüncü Yıl University, Tuşba 65080, Van, Turkey

Ibrahim Tümen: Bandirma Onyedi Eylul University, Faculty of Health Science, 10200, Bandirma, Turkey
}

\section{Introduction}

Rheumatoid arthritis is an inflammatory disease of unidentified etiology that has been recognized to occur since at least the 1800s [1]. It is the most severe of the inflammatory arthritis [2]. Recent evidence shows that rapid diagnosis and primary initiation of absolute diseasemodifying treatment can delay or stop the development of the disease and permit patients to retain function that would otherwise be lost in this progressive and commonly disabling disease [3]. Even though several drugs are known to treat chronic inflammatory disorders, prolonged use of these agents should be avoided due to severe side effects. Therefore, discovery of safe and new anti-inflammatory agents with fewer side effects is needed [4]. Consequently, traditional medicines contribute to discover new drug leads.

Bryonia L. (Cucurbitaceae) genus comprises perennial herbs with annual climbing or trailing stems. Bryonia genus has four species, namely $B$. multiflora, B. cretica, B. aspera, and B. alba, in the flora of Turkey. In the present study, B. alba L. was selected as a material due to its folkloric usage. The stems of $B$. alba are usually glandular, sometimes sparsely spiculate or hairy, and rarely glabrous. The leaves of the plant are narrowly to broadly ovate-cordate. The petiole of $B$. alba is glabrous or sparsely spiculate [5]. Bryonia species traditionally have been used as diuretic and laxative, to reduce edema and relieve joint pain [6-8]. B. alba roots are used especially to treat rheumatic pain and applied to painful joints for their anti-inflammatory properties [7,9]. The roots also exert an anti-inflammatory effect in the inflammation of the serous tissues and are used for treating rheumatism, pneumonia, and cough in traditional medicine [10,11].

Bryonia species are also known to have biological activities such as analgesic, anti-inflammatory, antioxidant, antipyretic, antimicrobial, larvicidal and cytotoxic [18]. Their constituents exert cytotoxic and antitumor effects [18]. Previous studies reported 
that $B$. alba might display preventive atherogenic or antiatherosclerotic activities [19]. Furthermore, there are some studies that prove the hepatoprotective activity of the root extract of $B$. alba [20] or even the protective activity for human cells against endogenous oxidative DNA damage.

Phytochemical studies have discovered that Bryonia species contain a variety of phytochemicals including polyphenols, flavonoids, cucurbitane-type triterpene glycosides, sterols, saponins, alkaloids, and carbohydrates $[12,13]$. Earlier phytochemical investigations of $B$. alba revealed the presence of saponarin, isovitexin, vitexin, lutonarin, and highly oxygenated and unsaturated bitter compounds, for example, the tetracyclic triterpenoid named cucurbitacin, polyhydroxy unsaturated fatty acids, essential oil, wax, tannins, carbohydrates, and amino acids [14-17].

The aim of the present study was to evaluate the antiinflammatory, antioxidant, and antinociceptive activities of $B$. alba roots.

\section{Experimental}

\subsection{Plant material}

Bryonia alba roots were collected from Cankırı, Ilgaz in June 2016 and were identified by Prof. Dr. Hayri Duman from the Department of Botany, Faculty of Science, Gazi University. Voucher specimens are deposited in the Herbarium of Faculty of Pharmacy, Gazi University (GUEF3466).

\subsection{Extraction procedure for the bioassays}

Shade-dried roots (500 g) of $B$. alba were successively extracted with $1500 \mathrm{~mL}$ of $n$-hexane, ethyl acetate (EtOAc), and methanol $(\mathrm{MeOH})$ at room temperature for 48 hours. The extracts were filtered and evaporated under reduced pressure at $40^{\circ} \mathrm{C}$ till dryness. The yields of each extract were $7.4 \%$ for $n$-hexane, $13.2 \%$ for ethyl acetate, and $35.7 \%$ for methanol.

\subsection{Determination of total phenolic content of the extracts}

Total phenolic contents of the extracts were measured using reference methods including the Folin-Ciocalteu reagent and gallic acid as standard compounds [23]. An aliquot of the extract solution $(100 \mu \mathrm{L})$ containing $1 \mathrm{mg}$ extract was taken into a volumetric flask. Distilled water and Folin-Ciocalteu reagent were added, and the flask was shaken thoroughly. Four milliliters $\mathrm{Na}_{2} \mathrm{CO}_{3}(75 \mathrm{~g} / \mathrm{L})$ was added, and the mixture was allowed to stand for 2 hours at room temperature with intermittent shaking. Then absorbance was measured at $765 \mathrm{~nm}$. The same procedure was applied to standard gallic acid solutions of different concentrations $(0.05,0.1,0.15,0.25$, and $0.5 \mathrm{mg} /$ $\mathrm{mL}$ ) to prepare the standard curve.

\subsection{Determination of total flavonoid contents}

The total flavonoid content of each plant extract was assessed using the method proposed by Zhishen et al. [24]. In brief, each sample $(1.0 \mathrm{~mL})$ was mixed with 4 $\mathrm{mL}$ of distilled water and subsequently with $0.30 \mathrm{~mL}$ of a $\mathrm{NaNO}_{2}$ solution $(10 \%)$. After 5 minutes, $0.30 \mathrm{~mL}$ of an $\mathrm{AlCl}_{3}$ solution (10\%) was added followed by $2.0 \mathrm{~mL}$ of $\mathrm{NaOH}$ solution (1\%). The absorbance was measured at 510 $\mathrm{nm}$ versus the blank after thorough mixing. The standard curve of rutin was prepared $(10-100 \mathrm{mg} / \mathrm{mL})$, and the results were expressed as rutin equivalents (mg rutin/g dried extract).

\subsection{Animals}

To assess the activities of the extracts, 120 mice were used for the anti-inflammatory and antinociceptive activities and each group included six rats. Swiss albino mice (20-25 g) were purchased from the animal breeding laboratories of Kobay A.Ş. (Ankara, Turkey). The animals left for 2 days for acclimatization to animal room conditions and were maintained on standard pellet diet and water ad libitum. Food was withdrawn on the day before the experiment, but free access to water was permitted. A minimum of six animals was used in each group, otherwise described in procedure. The present study was performed according to the international rules considering the animal experiments and biodiversity rights (Ethical Council Number: G.U.ET05.004).

\subsection{Preparation of test samples for bioassay}

Test samples were given orally to test animals after suspending in a mixture of distilled $\mathrm{H}_{2} \mathrm{O}$ and $0.5 \%$ sodium 
carboxymethyl cellulose (CMC). The control group animals received the same experimental handling as those of the test groups except that the drug treatment was replaced with appropriate volumes of the dosing vehicle. Indomethacin $(10 \mathrm{mg} / \mathrm{kg})$, morphine $(10 \mathrm{mg} / \mathrm{kg})$, and acetylsalicylic acid (ASA) (100 mg/kg) in 0.5\% CMC was used as reference drug.

\subsection{Anti-inflammatory activity}

\subsubsection{Carrageenan-induced hind paw edema model}

The carrageenan-induced hind paw edema model was used for determining the anti-inflammatory activity of the extract. After 60 minutes, a test sample or dosing vehicle was orally administered. A freshly prepared suspension of carrageenan $(0.5 \mathrm{mg} / 25 \mu \mathrm{L})$ in physiological saline (154 $\mathrm{nM} \mathrm{NaCl)}$ was injected to the subplantar tissue of the right hind paw of each mouse. As the control, $25 \mu \mathrm{L}$ of saline solution was injected into the left hind paw. Paw edema was then measured every 90 minutes for 6 hours after inducing inflammation. The difference in footpad thickness was measured using a gauge caliper (Ozaki Co., Tokyo, Japan). The mean values of treated groups were compared with those of a control group and analyzed using statistical methods. Indomethacin $(10 \mathrm{mg} / \mathrm{kg})$ was used as the reference drug [25].

\subsubsection{Acetic acid-induced increase in capillary permeability (Whittle method)}

The effect of the test samples on the increased vascular permeability induced by acetic acid in mice was determined according to the Whittle method with some modifications. Each test sample was administered orally to mice in $0.2 \mathrm{~mL}$ per $20 \mathrm{~g}$ of body weight. Each mouse was injected with $0.1 \mathrm{~mL}$ of $4 \%$ Evans blue (Sigma) in saline solution (intravenously) at the tail 30 minutes after the administration. Then, $0.4 \mathrm{~mL}$ of $0.5 \%$ (vol/vol) acetic acid was injected intraperitoneally 10 minutes after the intravenous injection of the dye solution. The mice were killed by dislocation of the neck after 20 minutes, and the viscera were exposed and irrigated with distilled water, which was then poured into $10 \mathrm{~mL}$ volumetric flasks through glass wool. Each flask was made up to $10 \mathrm{~mL}$ with distilled water, $0.1 \mathrm{~mL}$ of $0.1 \mathrm{~N} \mathrm{NaOH}$ solution was added to the flask, and the absorption of the final solution was measured at $590 \mathrm{~nm}$. In control mice, a mixture of distilled water and $0.5 \%$ CMC was given orally in the same manner as described earlier. Indomethacin $(10 \mathrm{mg} / \mathrm{kg})$ was used as the reference drug [25].

\subsection{Antinociceptive activity}

\subsection{1 p-Benzoquinone-induced abdominal constriction test}

This method was performed on mice for determining antinociceptive activity. The mice were intraperitoneally injected with $0.1 \mathrm{~mL}$ per $10 \mathrm{~g}$ of body weight of $2.5 \%$ (wt/ vol) $p$-benzoquinone solution in distilled water 60 minutes after the oral administration of a test sample. Control mice received an appropriate volume of dosing vehicle. The mice were then kept individually for the observation period, and the total number of the abdominal contractions (writhing movements) was determined for the following 15 minutes, starting 5 minutes after the $p$-benzoquinone injection. The data represented the average of the total number of writhes observed. The antinociceptive activity was then expressed as the percentage change from writhing controls. Acetylsalicylic acid at $100 \mathrm{mg} / \mathrm{kg}$ dose was used as the reference drug [25].

\subsubsection{Tail flick test}

The mice were detained in position with the tail extending out, and light heat was administered to the tail. Tail reaction times were then assessed 20, 40, and 60 minutes after vehicle or extract injection. A cut-off time of 10 seconds was used to avoid tissue damage [26]. Morphine at $10 \mathrm{mg} / \mathrm{kg}$ dose was used as the reference drug.

\subsection{Statistical analysis}

The results were expressed as mean \pm standard error of the mean. The ANOVA test was performed to determine the significant differences among groups using GraphPad Prism 6.0.

\subsection{Antioxidant activity}

\subsubsection{DPPH (2,2-Diphenyl-1-Picrylhydrazyl) radical- scavenging activity}

The scavenging activity of $B$. alba extracts against DPPH radical was evaluated using the method proposed by Blois 
(1958) [27] with some modifications. In this method, $1 \mathrm{~mL}$ of $B$. alba extract $(0.01 \mathrm{mg} \mathrm{dw} / \mathrm{mL})$ was mixed with $4 \mathrm{~mL}$ of $0.005 \mathrm{mg} / \mathrm{mL}$ DPPH methanol solution. The reaction mixture was vortexed thoroughly and left in the dark at room temperature for 30 minutes. The absorbance of the mixture was measured at $517 \mathrm{~nm}$ with ascorbic acid as reference. The ability to scavenge DPPH radicals was calculated using the following equation: DPPH radicalscavenging activity $(\%)=\left[\mathrm{Abs}_{\text {control }}-\mathrm{Abs}_{\text {sample }} / \mathrm{Abs}_{\text {control }}\right] \mathrm{x}$ 100 , where $\mathrm{Abs}_{\text {control }}$ is the absorbance of DPPH radicals in methanol and $\mathrm{Abs}_{\text {sample }}$ is the absorbance of DPPH radical solution mixed with sample extract/standard. All determinations were performed in triplicate.

\subsubsection{ABTS [2,2'-azinobis-(3-ethylbenzothiazoline-6- sulfonate)] radical-scavenging assay}

For the ABTS assay, the method proposed by Arnao et al. (2001) [28] was followed with some modifications. The stock solutions included $7 \mathrm{mM}$ ABTS solution and 2.4 $\mathrm{mM}$ potassium persulfate solution. The working solution was then prepared by mixing the two stock solutions in equal quantities and allowing them to react for 14 hours at room temperature in the dark. The solution was then diluted by mixing $1 \mathrm{~mL}$ of ABTS solution with $60 \mathrm{~mL}$ of methanol to obtain an absorbance of $0.706 \pm 0.01$ units at $734 \mathrm{~nm}$ using a spectrophotometer. Fresh ABTS solution was arranged for each analysis. Plant extracts $(1 \mathrm{~mL})$ were allowed to react with $1 \mathrm{~mL}$ of ABTS solution, and the absorbance was recorded at $734 \mathrm{~nm}$ after 7 minutes using a spectrophotometer. The ABTS-scavenging capacity of the extract was associated with that of ascorbic acid, and percentage inhibition was calculated as ABTS radicalscavenging activity $(\%)=\left[\mathrm{Abs}_{\text {control }}-\mathrm{Abs}_{\text {sample }} / \mathrm{Abs}_{\text {control }}\right]$ $\mathrm{x} 100$ where $\mathrm{Abs}_{\text {control }}$ is the absorbance of ABTS radicals in methanol and $\mathrm{Abs}_{\text {sample }}$ is the absorbance of ABTS radical solution mixed with sample extract/standard. All determinations were done in triplicate.

\subsubsection{Total antioxidant activity (ferric-reducing antioxidant power, FRAP)}

The FRAP assay was conducted according to the method proposed by Benzie and Strain (1996) [29] with some modifications. The stock solutions included $300 \mathrm{mM}$ acetate buffer $\left(3.1 \mathrm{~g} \mathrm{C}_{2} \mathrm{H}_{3} \mathrm{NaO}_{2} \times 3 \mathrm{H}_{2} \mathrm{O}\right.$ and $\left.16 \mathrm{~mL} \mathrm{C}_{2} \mathrm{H}_{4} \mathrm{O}_{2}\right)$, $\mathrm{pH}$ 3.6, 10mM 2,4,6-tripyridyl-s-triazine (TPTZ) solution in $40 \mathrm{mM} \mathrm{HCl}$, and $20 \mathrm{mM} \mathrm{FeCl}_{3} \times 6 \mathrm{H}_{2} \mathrm{O}$ solution. The fresh working solution was made by mixing $25 \mathrm{~mL}$ of acetate buffer, $2.5 \mathrm{~mL}$ of TPTZ solution, and $2.5 \mathrm{~mL}$ of $\mathrm{FeCl}_{3} \times 6 \mathrm{H}_{2} \mathrm{O}$ solution and kept at $37^{\circ} \mathrm{C}$ before use. B. alba extracts ( 0.15 $\mathrm{mL}$ ) were ready to react with $2.80 \mathrm{~mL}$ of the FRAP solution for 30 minutes in the dark. Readings of the colored product (ferrous tripyridyltriazine complex) were taken at 593 $\mathrm{nm}$. The standard curve was linear for 0.015 and $0.15 \mathrm{mM}$ Trolox. The results were expressed as mM TE/g dry mass. Additional dilution was required if the measured FRAP value was over the linear range of the standard curve. All determinations were made in triplicate.

\subsubsection{Hydroxyl radical-scavenging assay}

Hydroxyl radical-scavenging activity was measured as the ability of the extract to scavenge the hydroxyl radicals generated by the $\mathrm{Fe}^{3+}$-ascorbate-EDTA- $\mathrm{H}_{2} \mathrm{O}_{2}$ system. The reaction mixture in a final volume of $1.0 \mathrm{~mL}$ contained 100 $\mu \mathrm{L}$ of 2-deoxy-D-ribose (28mM in $20 \mathrm{mM} \mathrm{KH}_{2} \mathrm{PO}_{4}$ buffer, $\mathrm{pH}$ 7.4), $500 \mu \mathrm{L}$ of the extract at various concentrations $(50-800 \mu \mathrm{g} / \mathrm{mL})$ in buffer, $200 \mu \mathrm{L}$ of $(1.04 \mathrm{mM}$ EDTA and $\left.200 \mu \mathrm{M} \mathrm{FeCl}_{3}\right)(1: 1, \mathrm{v} / \mathrm{v}), 100 \mu \mathrm{L}$ of $1.0 \mathrm{mM}$ hydrogen peroxide $\left(\mathrm{H}_{2} \mathrm{O}_{2}\right)$, and $100 \mu \mathrm{L}$ of $1.0 \mathrm{mM}$ ascorbic acid. Test samples were kept at $37^{\circ} \mathrm{C}$ for 1 hour. The free radical damage forced on the substrate, deoxyribose, was measured using the thiobarbituric acid (TBA) test. Then, $1 \mathrm{~mL}$ of $1 \%$ TBA and $1.0 \mathrm{~mL}$ of $2.8 \%$ trichloroacetic acid were added to the test tubes and incubated at $100^{\circ} \mathrm{C}$ for 20 minutes. After cooling, the absorbance was measured at $532 \mathrm{~nm}$ against a blank containing deoxyribose and buffer. The scavenging activity on hydroxyl radicals was calculated as follows:

$$
\text { Inhibition \%: }\left(1-A / A_{0}\right)^{\prime} 100
$$

where $A_{0}$ is the absorbance of the negative control (without sample) at $532 \mathrm{~nm}$, and $A$ is the absorbance at $532 \mathrm{~nm}$ of the reaction mixture containing the sample [30].

\section{Results and Discussion}

B. alba roots are used especially to treat rheumatic pain and applied to painful joints traditionally in Turkey [7,9]. Therefore, the present study was performed to evaluate the anti-inflammatory, antinociceptive, and antioxidant activities of $n$-hexane, ethyl acetate, and methanol extracts prepared from $B$. alba roots.

The paw edema induced by carrageenan has been used widely for assessing the anti-inflammatory action of steroidal and nonsteroidal drugs containing numerous chemical mediators, including serotonin, bradykinin, 
Table 1: Effects of test materials on carrageenan-induced hind paw edema in mice.

\begin{tabular}{|c|c|c|c|c|c|}
\hline \multirow[t]{2}{*}{ Material } & \multirow[t]{2}{*}{ Dose (mg/kg) } & \multicolumn{4}{|c|}{ Swelling thickness $\left(\times 10^{-2} \mathrm{~mm}\right) \pm$ S.E.M. } \\
\hline & & $90 \mathrm{~min}$ & $180 \mathrm{~min}$ & $270 \mathrm{~min}$ & $360 \mathrm{~min}$ \\
\hline Control & - & $48.6 \pm 5.8$ & $52.6 \pm 7.3$ & $58.4 \pm 6.2$ & $67.9 \pm 5.1$ \\
\hline$n$-Hexane & 0.1 & $45.3 \pm 4.7$ & $46.9 \pm 8.2$ & $55.3 \pm 7.5$ & $58.4 \pm 6.9$ \\
\hline EtOAc & 0.1 & $37.5 \pm 4.2$ & $39.4 \pm 5.4$ & $40.6 \pm 4.8^{*}$ & $42.3 \pm 4.2^{\star *}$ \\
\hline $\mathrm{MeOH}$ & 0.1 & $42.1 \pm 5.6$ & $44.5 \pm 6.1$ & $52.7 \pm 5.9$ & $55.6 \pm 7.3$ \\
\hline Indomethacin & 10 & $35.4 \pm 3.5$ & $38.4 \pm 2.8^{*}$ & $37.7 \pm 3.1^{\star \star *}$ & $34.2 \pm 2.4^{\star *}$ \\
\hline
\end{tabular}

${ }^{\star} p<0.05 ;{ }^{\star \star} p<0.01 ;{ }^{\star \star \star} p<0.001$ significant from control.

Table 2: Effects of test materials on increased vascular permeability induced by acetic acid in mice.

\begin{tabular}{llll}
\hline Material & $\begin{array}{l}\text { Dose } \\
(\mathrm{mg} / \mathrm{kg})\end{array}$ & $\begin{array}{l}\text { Evans blue concentration } \\
(\mathrm{mean} \pm \text { S.E.M.) }(\mu \mathrm{g} / \mathrm{mL})\end{array}$ & Inhibition (\%) \\
\hline Control & - & $10.6 \pm 1.3$ & \\
$n$-Hexane & 0.1 & $9.7 \pm 2.1$ & 8.5 \\
EtOAC & 0.1 & $6.7 \pm 0.9$ & $36.8^{\star}$ \\
MeOH & 0.1 & $9.1 \pm 1.6$ & 14.2 \\
Indomethacin & 10 & $5.5 \pm 0.4$ & $48.1^{\star \star *}$ \\
\hline
\end{tabular}

${ }^{\star} p<0.05 ;{ }^{* \star} p<0.01 ;{ }^{* \star \star} p<0.001$ significant from control.

Table 3: Effects of the extracts against $p$-benzoquinone-induced writhings in mice.

\begin{tabular}{llll}
\hline Material & $\begin{array}{l}\text { Dose } \\
(\mathrm{mg} / \mathrm{kg})\end{array}$ & $\begin{array}{l}\text { Number of writhings } \\
\text { (mean } \pm \text { S.E.M.) }\end{array}$ & $\begin{array}{l}\text { Inhibition } \\
(\%)\end{array}$ \\
\hline Control & - & $39.5 \pm 7.4$ & \\
n-Hexane & 0.1 & $35.8 \pm 6.8$ & 9.4 \\
EtOAC & 0.1 & $26.0 \pm 4.3$ & $\mathbf{3 4 . 2}^{\star \star}$ \\
MeOH & 0.1 & $34.4 \pm 6.1$ & 12.9 \\
Aspirin & 100 & $21.5 \pm 2.2$ & $45.6^{\star \star *}$ \\
\hline
\end{tabular}

${ }^{\star} p<0.05 ;{ }^{\star \star} p<0.01 ;{ }^{\star \star \star} p<0.001$ significant from control.

histamine, and prostaglandins [31]. Histamine, serotonin, and similar substances are released in the initial phase (90-180 minutes) of the inflammation. Prostaglandins, proteases, and lysosomes are activated in the later phase (270-360 minutes) [32]. The EtOAc extract of B. alba roots showed a statistically significant anti-inflammatory activity in carrageenan-induced hind paw edema model and acetic acid-induced increase in capillary permeability (Tables 1 and 2).

Furthermore, the EtOAc extract displayed antinociceptive activity in the $p$-benzoquinone-induced writhing mouse model (Table 3). Acetic acid and $p$-benzoquinone mouse models are simple and fast for the screening of antinociceptive activity [33]. Furthermore, they involve complex mechanisms, including the production of pro-inflammatory cytokines and opening of ion channels [34,35]. Acetic acid-induced writhing mechanism depends on the activation of peritoneal macrophages and mast cells, which leads to the release of cytokines, such as tumor necrosis factor alpha and interleukin (IL)-1⿴囗十 as well as sympathomimetic amines and eicosanoids [36]. However, the $p$-benzoquinoneinduced writhing model depends on the cytokines IL-18, interferon gamma, and endothelin-1 [35]. Nevertheless, the acetic acid and $p$-benzoquinone models share nociceptive mechanisms such as prostanoids, other cytokines such as IL-33 [37], susceptibility to opioid treatment [35,38], and mitogen-activated phosphatidylinositol 3-kinase and protein kinase [39]. In addition, none of the extracts obtained from B. alba roots showed any activity in the tail flick test in the present study (Table 4). The tail flick test usually is conducted to appraise the analgesic activities of opioids [40]. In our study, since any extract obtained from the roots of $B$. alba did not show any activity in the tail flick test, it was concluded that B. alba roots did not show their analgesic activities through the opioid receptors.

The EtOAc extract showed strong DPPH and ABTS radical-scavenging activity when the antioxidant parameters of the extracts were evaluated (Table 5). Furthermore, when compared to the extracts according to phytochemical contents, the EtOAc extract was found 
Table 4: Effects of the extracts on tail flick test.

\begin{tabular}{|c|c|c|c|c|c|}
\hline \multirow[t]{2}{*}{ Material } & \multirow[t]{2}{*}{ Dose (mg/kg) } & \multicolumn{4}{|c|}{ Time after injection } \\
\hline & & $0 \mathrm{~min}$ & $20 \mathrm{~min}$ & $40 \mathrm{~min}$ & $60 \mathrm{~min}$ \\
\hline Control & - & $3.4 \pm 1.1$ & $3.3 \pm 0.9$ & $3.5 \pm 1.3$ & $3.2 \pm 0.8$ \\
\hline$n$-Hexane & 0.1 & $3.6 \pm 0.9$ & $3.8 \pm 0.3$ & $3.6 \pm 0.7$ & $3.5 \pm 0.9$ \\
\hline EtOAc & 0.1 & $3.1 \pm 1.2$ & $3.1 \pm 0.6$ & $3.3 \pm 0.2$ & $3.2 \pm 0.3$ \\
\hline $\mathrm{MeOH}$ & 0.1 & $3.3 \pm 1.8$ & $3.7 \pm 0.8$ & $3.4 \pm 0.5$ & $3.1 \pm 0.6$ \\
\hline Morphine & 10 & $3.4 \pm 1.2$ & $6.2 \pm 0.2^{*}$ & $5.5 \pm 0.7^{*}$ & $5.3 \pm 0.1^{\star}$ \\
\hline
\end{tabular}

${ }^{*} p<0.05 ;{ }^{* *} p<0.01 ;{ }^{* * *} p<0.001$ significant from control.

Table 5: Antioxidant activity of the extracts obtained from B. alba roots.

\begin{tabular}{lllll}
\hline Extracts & $\begin{array}{l}\text { FRAP } \\
(\mu \mathrm{M} \mathrm{TE} / \mathrm{g} \mathrm{dw})\end{array}$ & $\begin{array}{l}\text { DPPH } \\
\%\end{array}$ & $\begin{array}{l}\text { ABTS } \\
\%\end{array}$ & $\begin{array}{l}\text { OH } \\
\%\end{array}$ \\
\hline $\boldsymbol{n}$-Hexane & $9.1 \pm 0.4^{\mathrm{a}}$ & $28.9 \pm 0.2^{\mathrm{a}}$ & $35.4 \pm 0.3^{\mathrm{a}}$ & $11.3 \pm 0.8^{\mathrm{a}}$ \\
EtOAc & $66.3 \pm 0.8^{\mathrm{c}}$ & $82.6 \pm 0.4^{\mathrm{c}}$ & $87.1 \pm 0.2^{\mathrm{c}}$ & $26.5 \pm 0.5^{\mathrm{b}}$ \\
MeOH & $38.7 \pm 0.6^{\mathrm{b}}$ & $53.2 \pm 0.5^{\mathrm{b}}$ & $62.8 \pm 0.3^{\mathrm{b}}$ & $21.9 \pm 0.4^{\mathrm{b}}$ \\
Ascorbic acid & $81.2 \pm 0.2^{\mathrm{d}}$ & $92.1 \pm 0.7^{\mathrm{d}}$ & $96.8 \pm 0.6^{\mathrm{c}}$ & $56.8 \pm 0.3^{\mathrm{c}}$ \\
\hline
\end{tabular}

Values with different letters are significantly different at $p<0.05$; All determinations were performed in triplicate (mean \pm S.E.M.)

Table 6: Total phenolic, flavonoid, and tannin contents of the extracts.

\begin{tabular}{lll}
\hline Extracts & Total Phenol Content (mg of GA/g of extract) & Total Flavonoid Content (mg of RU/g of extract) \\
\hline $\boldsymbol{n}$-Hexane extract & $13.91 \pm 0.37^{\mathrm{a}}$ & $18.67 \pm 0.30^{\mathrm{a}}$ \\
EtOAc extract & $44.35 \pm 0.54^{\mathrm{b}}$ & $54.71 \pm 0.47^{\mathrm{b}}$ \\
MeOH extract & $31.54 \pm 0.86^{\mathrm{a}}$ & $26.49 \pm 0.38^{\mathrm{a}}$ \\
\hline
\end{tabular}

Values are expressed as mean \pm SEM of three replicates

to have the highest total phenolic and flavonoid contents (Table 6).

B. alba has demonstrated its significance in folk medicine mainly as purgative and mostly due to cucurbitacin content [41-43]. Besides cucurbitacins, which are the most significant compounds presented in $B$. alba extract, other compounds in the extract, such as lectins, flavonoids, and lipids, also act synergistically to increase the biological activity [44]. Previous studies showed the significance of cucurbitacins isolated from B. alba, particularly cucurbitacins B, D, E, I, and their derivatives, owing to their therapeutic effect or adjuvant management [45-47]. Cucurbitacins J, K, and L are found in significant amounts in the roots [41,48] and exert cytotoxic effects [41]. Other studies demonstrated the antiatherosclerotic and atherogenic activities of trihydroxyoctadecadienoic acids in B. alba [49]. Meanwhile, a few studies demonstrated the hepatoprotective activity of the root extract [10] on human cells contrary to endogenous oxidative DNA damage, although its capability to protect against oxidative DNA damage could not be verified [50]. B. alba roots are also known for their adaptogenic activity, which is related to their cucurbitacin content and which improves the sensitivity to stress due to the effects of eicosanoids and corticosteroids. Gupta et al. [51] reported that the chloroform extract of $B$. laciniosa leaves had antiinflammatory activity and inhibited peritoneal leukocyte migration in mice. Konopa et al. [48] isolated cucurbitacins from B. alba having cytotoxic and antitumor effects. Ukiya et al. [52] isolated cucurbitane-type triterpenoids from $B$. dioica roots. All isolated compounds were tested for their anti-inflammatory activity. The tested compounds displayed marked anti-inflammatory effects, with 50\% inhibitory doses $\left(\mathrm{ID}_{50}\right)$ of $0.2-0.6 \mathrm{mg}$. In fact, B. alba roots also increased nitric oxide (NO) concentration in humans, which might be responsible for the adaptation 
of humans to heavy physical workout [42]. In contrast, the production of the same NO molecule, which is responsible for many inflammatory processes, is inhibited by $B$. alba roots by inhibiting the activity of inducible NO synthase, which might be the mechanism underlying the antiinflammatory effect $[53,54]$.

It has been reported that the EtOAc extract has high phenolic content in the present study. A previous study conducted by Ambriz-Pérez et al. [55] exhibited that phenolic compounds work like nonsteroidal antiinflammatory drugs (NSAIDs), furthermore some NSAIDs inhibit pro-inflammatory mediators besides cyclooxygenase by inhibiting their activity or gene expression. Besides, some phenolic compounds can up/down regulate transcriptional factors, like nuclear factor-kB, in inflammatory and antioxidant pathways [55].

The anti-inflammatory, antinociceptive, and antioxidant activities of $B$. alba roots could be attributed to its phenolic compounds and cucurbitane-type triterpenoids.

\section{Conclusions}

In the present study, EtOAc extract prepared from B. alba roots showed statistically significant anti-inflammatory, antinociceptive, and antioxidant activities. Therefore, B. alba roots might serve as an alternative treatment for rheumatic disorders. In further analysis, bioassay guided fractionation and isolation studies should be conducted for discovering potential new anti-inflammatory agents.

Conflict of interest: Authors declare no conflict of interest.

\section{References}

[1] Aceves-Avila F.J., Medina F., Fraga A., The antiquity of rheumatoid arthritis: A reappraisal, J. Rheumatol., 2001, 28(4), 751-757.

[2] Silman A.J., The changing face of rheumatoid arthritis: why the decline in incidence?, Arthritis Rheum., 2002, 46(3), 579-581.

[3] Emery P., Pocket reference to early rheumatoid arthritis, Springer, London, UK, 2011.

[4] Küpeli, E., and Yesilada, E., Flavonoids with anti-inflammatory and antinociceptive activity from Cistus laurifolius L. leaves through bioassay-guided procedures, J. Ethnopharmacol., 2007, 112, 524-530.

[5] Jeffrey C., Bryonia L., In: Davis P.H. (Ed.), Flora of Turkey and the East Aegean Islands. vol. 4, University of Edinburgh, Edinburgh, 1972.
[6] Kaval I., Behcet L., Cakilcioglu U., Ethnobotanical study on medicinal plants in Gecitli and its surrounding (HakkariTurkey), J. Ethnopharmacol., 2014, 155(1), 171-184.

[7] Leporatti M.L., and Ivancheva S., Preliminary comparative analysis of medicinal plants used in the traditional medicine of Bulgaria and Italy, J. Ethnopharmacol., 2003, 87, 123-142.

[8] Ozudogru B., Akaydin G., Erik S., Yesilada E., Inferences from an ethnobotanical field expedition in the selected locations of Sivas and Yozgat provinces (Turkey), J. Ethnopharmacol., 2011, 137(1), 85-98.

[9] Yesilada E., Honda G., Sezik E., Tabata M., Fujita T., Tanaka T., Takeda Y., Takaishi Y., Traditional medicine in Turkey. V. Folk medicine in the inner Taurus Mountains, J. Ethnopharmacol., 1995, 46(3), 133-152.

[10] Manvi M., and Prasad Garg G., Evaluation of pharmacognostical parameters and hepatoprotective activity in Bryonia alba Linn, J. Chem. Pharm. Res., 2011, 3(6), 99-109.

[11] Volz S.M., and Renner S.S., Phylogeography of the ancient Eurasian medicinal plant genus Bryonia (Cucurbitaceae) inferred from nuclear and chloroplast sequences, Taxon, 2009, 58(2), 550-560.

[12] Akihisa T., Kimura Y., Kokke W.C.M.C., T. I., T. T., Eight novel sterols from the roots of Bryonia dioica JACQ, Chem. Pharm. Bull. (Tokyo), 1996, 44, 1202-1207.

[13] Oobayashi K., Yoshikawa K., Arihara S., Structural revision of bryonoside and structure elucidation of minor saponins from Bryonia dioica, Phytochemistry, 1992, 31(3), 943-946.

[14] Charrette G., Homeopatische Arzneimittellehre fur die Praxis, Hippokrates, Stuttgart, 1987.

[15] Imperato F., Five plants of the family Cucurbitaeeae with flavonoid patterns of pollens different from those of corresponding stigmas, Experientia, 1980, 36, 1136-1137.

[16] Krauze M., and Cisowski W., Flavone C-glycosides from Bryonia alba and B. dioica, Phytochemistry, 1995, 39(3), 727-729.

[17] Zepernick B., Langhammer L., Lidcke J.B.P., Lexikon der Offizinallen Arzneipflanzen, Gruyter, New York, 1984.

[18] Ielciu I., Frédérich M., Tits M., Angenot L., Păltinean R., Cieckiewicz E., Crişan G., Vlase L., Bryonia alba L. and Ecballium elaterium (L.) A. Rich. - two related species of the Cucurbitaceae family with important pharmaceutical potential, Farmacia, 2016, 64(3), 323-332.

[19] Orekhov A.N., and Panossian A.G., Trihydroxy-octadecadienoic acids exhibit antiatherosclerotic and antiatherogenic activity, Phytomedicine, 1994, 1(2), 123-126.

[20] Manvi M., and Prasad Garg G., Evaluation of pharmacognostical parameters and hepatoprotective activity in Bryonia alba Linn., J. Chem. Pharm. Res., 2011, 3(6), 99-109.

[21] Nersesyan A.K., and Collins A.R., The effect of "Loshtak" preparation on exogenous and endogenous oxidative DNA damage in transformed human cells. Exp. Oncol., 2002, 24, 51-54.

[22] Panossian A.G., Oganessian A.S., Ambartsumian M., Gabrielian E.S., Wagner H., Wikman G., Effects of heavy physical exercise and adaptogens on nitric oxide content in human saliva. Phytomedicine, 1999, 6(1), 17-26.

[23] Spanos G.A., and Wrolstad R.E., Influence of processing and storage on the phenolic composition of Thompson seedless grape juice, J. Agric. Food Chem., 1990, 38, 1565-1571. 
[24] Zhishen J., Mengcheng T., Jianming W., The determination of flavonoid contents in mulberry and their scavenging effects on superoxide radicals, Food Chem., 1999, 64(4), 555-559.

[25] Yesilada E., and Kupeli E., Clematis vitalba L. aerial part exhibits potent anti-inflammatory, antinociceptive and antipyretic effects, J. Ethnopharmacol., 2007, 110(3), 504-515.

[26] Ark M., Üstün O., Yeşilada E., Analgesic activity of Cistus laurifolius in mice, Pharm. Biol., 2004, 42(2), 176-178.

[27] Blois M.S., Antioxidant determinations by the use of a stable free radical, Nature, 1958, 181, 1199-1200.

[28] Arnao M.B., Cano A., Acosta M., The hydrophilic and lipophilic contribution to total antioxidant activity, Food Chem., 2001, 73(2), 239-244.

[29] Benzie I.F., and Strain J.J., The ferric reducing ability of plasma (FRAP) as a measure of "antioxidant power": The FRAP assay, Anal. Biochem., 1996, 239, 70-76.

[30] Olugbami J.O., Gbadegesin M.A., Odunola O.A., In vitro free radical scavenging and antioxidant properties of ethanol extract of Terminalia glaucescens, Pharmacognosy Res., 2015, 7(1), 49-56.

[31] Vinegar R., Truax J.F., Selph J.L., Johnston P.R., Venable A.L., McKenzie K.K., Pathway to carrageenan-induced inflammation in the hind limb of the rat, Fed. Proc., 1987, 46(1), 118-126.

[32] Olajide O.A., Makinde J.M., Awe S.O., Effects of the aqueous extract of Bridelia ferruginea stem bark on carrageenaninduced oedema and granuloma tissue formation in rats and mice, J. Ethnopharmacol., 1999, 66(1), 113-117.

[33] Martinez R.M., Zarpelon A.C., Domiciano T.P., Georgetti S.R., Baracat M.M., Moreira I.C., Andrei C.C., Verri W.A., Jr., Casagrande R., Antinociceptive effect of Tephrosia sinapou extract in the acetic acid, phenyl-p-benzoquinone, formalin, and complete freund's adjuvant models of overt pain-like behavior in mice, Scientifica (Cairo), 2016, 2016, 8656397.

[34] Verri W.A., Jr., Cunha T.M., Ferreira S.H., Wei X., Leung B.P., Fraser A., McInnes I.B., Liew F.Y., Cunha F.Q., IL-15 mediates antigen-induced neutrophil migration by triggering IL-18 production, Eur. J. Immunol., 2007, 37(12), 3373-3380.

[35] Verri W.A., Jr., Cunha T.M., Magro D.A., Domingues A.C., Vieira S.M., Souza G.R., Liew F.Y., Ferreira S.H., Cunha F.Q., Role of IL-18 in overt pain-like behaviour in mice, Eur. J. Pharmacol., 2008, 588(2-3), 207-212.

[36] Ribeiro R.A., Vale M.L., Thomazzi S.M., Paschoalato A.B., Poole S., Ferreira S.H., Cunha F.Q., Involvement of resident macrophages and mast cells in the writhing nociceptive response induced by zymosan and acetic acid in mice, Eur. J. Pharmacol., 2000, 387(1), 111-118.

[37] Magro D.A., Hohmann M.S., Mizokami S.S., Cunha T.M., Alves-Filho J.C., Casagrande R., Ferreira S.H., Liew F.Y., Cunha F.Q., Verri W.A., Jr., An interleukin-33/ST2 signaling deficiency reduces overt pain-like behaviors in mice, Braz. J. Med. Biol. Res., 2013, 46(7), 601-606.

[38] Verri Jr. W.A., Cunha T.M., Poole S., Ferreira S.H., Cunha F.Q., Cytokine inhibitors and pain control, Rev. Bras. Reumatol., 2007, 47(5), 341-353.

[39] Pavao-de-Souza G.F., Zarpelon A.C., Tedeschi G.C., Mizokami S.S., Sanson J.S., Cunha T.M., Ferreira S.H., Cunha F.Q., Casagrande R., Verri W.A., Jr., Acetic acid- and phenyl-pbenzoquinone-induced overt pain-like behavior depends on spinal activation of MAP kinases, $\mathrm{PI}(3) \mathrm{K}$ and microglia in mice, Pharmacol. Biochem. Behav., 2012, 101(3), 320-328.
[40] Wang J.J., Ho S.T., Hu O.Y.P., Chu K.M., An innovative cold tailflick test: The cold ethanol tail-flick test, Anesth. Analg., 1995, 80, 102-107.

[41] Baek N.I., Lee D.W., Lee Y.H., Kim S., Aprikian G.V., Cytotoxic constituents from the root of Bryonia alba, Nat. Prod. Sci., 1995, 1(1), 43-49.

[42] Panossian A., Gabrielian E., Wagner H., On the mechanism of action of plant adaptogens with particular reference to cucurbitacin R diglucoside, Phytomedicine, 1999, 6(3), 147-155.

[43] Panosyan A.G., Nikishchenko M.N., Avetisyan G.M., Structure of 22-deoxocucurbitacins isolated from Bryonia alba and Ecbalium elaterium, Chem. Nat. Compd., 1986, 21(5), 638-645.

[44] Hashemzaei M., Karami S.P., Delaramifar A., Sheidary A., Tabrizian K., Rezaee R., Shahsavand S., Arsene A.L., Tsatsakis M., Taghdisi S.M., Anticancer effects of co-administration of daunorubicin and resveratrol in MOLT-4, U266 B1 and RAJI cell lines, Farmacia, 2016, 64(1), 36-42.

[45] Gogilashvili L.M., and Kemertelidze E.P., Lectin from Bryonia alba roots, Chem. Nat. Compd., 2000, 36(4), 399-401.

[46] Karageuzyan K.G., Vartanyan G.S., Agadjanov I., Panossian G., Hoult J.R.S., Restoration of the disordered glucose-fatty acid cycle in alloxandiabetic rats by trihydroxyoctadecadienoic acids from Bryonia alba, a native Armenian medicinal plant, Planta Med., 1998, 64(5), 417-422.

[47] Karpyuk U.V., Kislichenko V.S., Gur'eva I.G., HPLC determination of free and bound amino acids in Bryonia alba, Chem. Nat. Compd., 2015, 51(2), 399-400.

[48] Konopa J., Matuszkiewicz A., Hrabowska M., Onoszka K., Cucurbitacines, cytotoxic and antitumor substances from Bryonia alba L. Part II: Biological studies, Arzneimittelforschung, 1974, 24(11), 1741-1743.

[49] Orekhov A.N., and Panossian A.G., Trihydroxyoctadecadienoic acids exhibit antiatherosclerotic and antiatherogenic activity, Phytomedicine, 1994, 1(2), 123-126.

[50] Nersesyan A.K., and Collins A.R., The effect of "Loshtak" preparation on exogenous and endogenous oxidative dna damage in transformed human cells, Exp. Oncol., 2002, 24, 51-54.

[51] Gupta M., Mazumdar U.K., Sivakumar T., Vamsi M.L., Karki S.S., Sambathkumar R., Manikandan L., Evaluation of antiinflammatory activity of chloroform extract of Bryonia laciniosa in experimental animal models, Biol. Pharm. Bull., 2003, 26(9), $1342-1344$.

[52] Ukiya M., Akihisa T., Yasukawa K., Tokuda H., Toriumi M., Koike K., Kimura Y., Nikaido T., Aoi W., Nishino H., Takido M., Antiinflammatory and anti-tumor-promoting effects of cucurbitane glycosides from the roots of Bryonia dioica, J. Nat. Prod., 2002, 65(2), 179-183.

[53] Conea (Suciu) S., Pârvu A.E., Balboaca S., Antiinflammatory effects of Eryngium planum L. and E. maritimum L. (Apiaceae) extracts in turpentine-oil induces acute inflammation in rats, Farmacia, 2016, 64(2), 291-293.

[54] Park C.S., Lim H., Han K.J., Baek S.H., Sohn H.O., Lee D.W., Kim Y.G., Yun H.Y., Baek K.J., Kwon N.S., Inhibition of nitric oxide generation by 23,24-dihydrocucurbitacin $D$ in mouse peritoneal macrophages, J. Pharmacol. Exp. Ther., 2004, 309(2), 705-710.

[55] Ambriz-Pérez D.L., Leyva-López L., Gutierrez-Grijalva E.P., Heredia, J.B., Phenolic compounds: Natural alternative in inflammation treatment. A Review, Cogent Food Agric., 2016, 2, 1131412. 